RECENZJE

PAWEL MOMRO

\title{
Prezydentura polska w pierwszych latach III RP
}

Wydawnictwo von borowiecky, Radzymin 2019, s. 422

Na temat prezydentury w pierwszych latach III Rzeczypospolitej Polskiej napisano już wiele i to zarówno z punktu widzenia prawnokonstytucyjnego, jak i nauk politycznych. Tym razem chodzi o ustalenie związku między sposobem korzystania z kompetencji prezydenta PRL i prezydenta RP w pierwszych latach transformacji ustrojowej przez osoby sprawujące tę funkcję a linią polityczną, jaką reprezentowali po objęciu urzędu. Kompetencje prezydenckie stanowią istotny instrument $\mathrm{w}$ realizowaniu linii politycznej osoby piastującej stanowisko głowy państw. W badanym okresie poddane zostało to wielostronnym analizom odnośnie do prezydentury zarówno gen. Wojciecha Jaruzelskiego, jak Lecha Wałęsy.

Słowa kluczowe: nowela z 7 kwietnia 1989 r. Konstytucji PRL, ustawa konstytucyjna z 17 października 1992 r., Prezydent PRL, Prezydent RP, cybernetyczny typ analizy decyzyjnej

\section{Polish presidency in the first years of the Third Republic of Poland}

Much had been written on presidency in the first years of the Third Republic of Poland, both from the legal-constitutional and political science perspectives. This time, it is about establishing a connection between the manner of exercising the competences of the President of the People's Republic of Poland and the President of the Republic of Poland in the first years of the systemic transformation by persons exercising this function on the one hand and the policy they represented after obtaining the office. Presidential competences are an important instrument in realizing the policy of a person holding the office of the head of state. In the analyzed period this aspect had been subject to multisided examination as regards the presidency of both general Wojciech Jaruzelski and Lech Wałęsa.

Key words: amendment of 7 April 1989 to the Constitution of the People's Republic of Poland, Constitutional Act of 17 October 1992, President of the People's Republic of Poland, President of the Republic of Poland, cybernetic decision-making analysis model

$\mathrm{Na}$ temat prezydentury w pierwszych latach III Rzeczypospolitej Polskiej napisano już wiele i to zarówno z punktu widzenia prawnokonstytucyjnego, jak i nauk politycznych. Tym razem chodzi o ustalenie związku między sposobem korzystania z kompetencji prezydenta PRL i prezydenta RP w pierwszych latach transformacji ustrojowej przez osoby sprawujące tę funkcję a linią polityczną, jaką reprezentowali po objęciu urzędu. Tezą pracy jest, że kompetencje prezydenckie stanowią istotny instrument w realizowaniu linii politycznej osoby piastującej stanowisko głowy państwa w badanym okresie, co poddane zostało wielostronnym analizom. Zajął się tą sprawą Paweł Momro w swojej pracy doktorskiej, która w wersji książkowej jest przedmiotem niniejszej recenzji. 
Już na samym początku należy wyrazić zdziwienie. Co prawda, we „Wstępie” jest podana informacja, że mamy do czynienia z rozprawą doktorską obronioną w kwietniu 2018 r. na Wydziale Politologii Uniwersytetu Pedagogicznego w Krakowie, ale nie wiemy, kto był promotorem, nie są znane też nazwiska recenzentów (te ostatnie widnieją na stronie informacyjnej książki oraz na czwartej stronie okładki). Chyba pierwszy raz w życiu spotykam się z taką sytuacją. Dobry obyczaj akademicki nakazywałaby inne zachowanie.

Nieprecyzyjnie też jest określony przedmiot badań P. Momro. Jeśli mowa o III RP, to na pewno nie bierze ona swego początku wraz z nowelą konstytucji PRL z 7 kwietnia 1989 r. (s. 13). Niejasna jest też data końcowa tytułowych ,pierwszych lat III RP”. Autor napisał we „Wstępie”, że chodzi mu o moment zakończenia kadencji prezydenckiej Lecha Wałęsy, a więc grudzień 1995 r. (s. 14). Z kolei z wielu innych uwag wynika, że tą datą końcową powinna być uchwalona Konstytucja RP, czyli 2 kwietnia 1997 r. Wydaje się, że ta ostatnia data byłaby właściwsza, bo dopiero w tym momencie Polska ostatecznie wychodzi z okresu prowizorium konstytucyjnego, a więc w sensie instytucjonalnym kończyłyby się ,pierwsze lata III RP”. Gdyby przyjąć takie stanowisko, pracę należałoby uzupełnić o część dotyczącą analizy początkowego okresu prezydentury Aleksandra Kwaśniewskiego. Z pewnością nie tylko pełniej odpowiadałoby to tytułowi książki, ale wzbogaciłoby też badania P. Momro.

Monografia składa się z pięciu rozdziałów podzielonych na dwie części, całość dopełnia indeks osobowy. Wrażenie robi obszerna bibliografia, niestety nie jest ona sporządzona dostatecznie starannie. Po wyrywkowym sprawdzeniu okazuje się, że np. w wykazie książek nie umieszczono pracy Zbigniewa Gacha, Antybohater, Wrocław 1991. Może w tej sytuacji bezpieczniej byłoby używać określenia „Wybrana bibliografia” zamiast „Bibliografia”?

Rozdział 1 zawiera skrótowy opis ewolucji urzędu głowy państwa w Polsce w latach 1918-1989. Wydawałoby się, że ze względu choćby na istnienie obszernej literatury przedmiotu i sprawozdawczy charakter tego rozdziału nie powinno być błędów, ale tak nie jest. System rządów zawarty w ustawie konstytucyjnej z 23 kwietnia 1935 r. trudno uznać za ,prezydencki” (s. 34), skoro utrzymany został dualizm władzy wykonawczej. Wielokrotnie wyjaśniano w literaturze prawnokonstytucyjnej zarówno polskiej, jak i obcej, że występowanie tej cechy przesądza, że nie mamy do czynienia z systemem prezydenckim. Nie jest prawdą również, że byt Rady Ministrów został uniezależniony od woli parlamentu (s. 35) albo że doszło do ,trwałego wyrugowania" parlamentu z powoływania i odwoływania Rady Ministrów (s. 37). Treść art. 29 świadczy o czymś innym. Gdyby autorowi znane były postanowienia kwietniowej ustawy konstytucyjnej albo zapoznał się z klasyczną już pracą Dariusza Góreckiego, Pozycja ustrojowo-prawna Prezydenta Rzeczypospolitej i rządu w ustawie konstytucyjnej z 23 kwietnia 1935 r., Łódź 1992, zakwalifikowałby te rozwiązania ustrojowe do jakiegoś rodzaju rządów parlamentarnych, przy okazji unikając oczywistych błędów. Także problem ciągłości państwa polskiego w kontekście wydarzeń z lat 1944-1945 - głównie chodzi o istnienie wówczas dwóch polskich rządów — był wielokrotnie 
w literaturze prawniczej wyjaśniany. Ostatnio było to na łamach „Państwa i Prawa” w latach 1998-1999 (por. artykuły Romana Kwietnia, Grzegorza Górskiego i Władysława Czaplińskiego). Konkluzją tych rozważań jest stwierdzenie o zachowaniu po II wojnie światowej w sensie prawnomiędzynarodowym ciągłości państwa polskiego przy zerwaniu jej w stosunkach wewnętrznych. Wynika z tego, że na przełomie lat 1989/1990 mogło dojść w Polsce jedynie do zmiany władz naczelnych państwa przy utrzymaniu dotychczasowej ciągłości prawnomiędzynarodowej państwa, ale z zerwaniem ciągłości w stosunkach wewnętrznych, podobnie jak 40 lat wcześniej, acz wektor zmian wewnętrznych był oczywiście inny. Błędnie o tym wszystkim pisze P. Momro (s. 46, 49-51). I jeszcze dwie uwagi na marginesie. 22 czerwca 1940 r. nie mieliśmy do czynienia z kapitulacją Francji wobec Niemiec (s. 42), a z zawarciem zawieszenia broni, a to przecież nie to samo i to mimo katastrofalnego przebiegu wojny dla Francji. Gen. Tadeusz Bór-Komorowski nie był zaś jakimś ,„przywódcą Powstania Warszawskiego" (s. 44), pełnił natomiast funkcję Komendanta Głównego Armii Krajowej, ale walkami powstańczymi w Warszawie dowodził kto inny.

Z lektury dalszych części pracy wynika, że ustalenia poczynione w rozdziale 1 nie mają żadnego znaczenia dla późniejszych analiz, P. Momro w ogóle z nich nie korzysta. W takiej sytuacji rozdział ten pełni wyłącznie charakter rysu historycznego czy pewnego rodzaju ozdobnika, zamiast stać się źródłem porównawczej wiedzy dla głównych rozważań zawartych w książce. To z pewnością należy uznać za błąd.

Rozdział 2 zawiera analizę prezydenckich kompetencji w latach 1989-1995. Poczynione tu ustalenia są na ogół poprawne. Jednak absolutną nieprawdą jest stwierdzenie, że instytucja kontrasygnaty ,znana (jest) w polskiej tradycji ustrojowej od czasu Konstytucji kwietniowej z 1935 roku" (s. 59), gdyż mowa o niej już w art. 4 dekretu z 22 listopada 1918 r. o najwyższej władzy reprezentacyjnej Republiki Polskiej (Dz.P.K.P. nr 17, poz. 41). Błędna jest sugestia, jakoby w skład noweli z 7 kwietnia 1989 r. konstytucji PRL wchodziło coś więcej niż sama ta nowela konstytucyjna (s. 67), bowiem uchwalone tego samego dnia ordynacje wyborcze do Sejmu (Dz.U. nr 19, poz. 102) i do Senatu (ibidem, poz. 103) są jedynie ustawami zwykłymi. Nie wiem, dlaczego autor przy analizie kompetencji prezydenta PRL odwołuje się jedynie do modelu prezydentury V Republiki Francuskiej (s. 69), całkowicie zapominając o zbieżnościach z rozwiązaniami zawartymi w ustawie konstytucyjnej z 23 kwietnia 1935 r. Doskonale o tym świadczy choćby dokonane przezeń wylistowanie kompetencji prezydenta PRL / prezydenta RP w latach 1989-1995 (s. 112-113). Gdyby autor skorzystał ze swoich rozważań zawartych w rozdziale 1, nie miałby problemu ze sformułowaniem takiej konkluzji. Niezrozumiałe są także uwagi o ustawie z 25 stycznia 1982 r. o szczególnej regulacji prawnej w okresie stanu wojennego w kontekście walidacji przez nią dekretów Rady Państwa z 12-13 grudnia 1981 r. (s. 87). Napisałem o tym obszernie wraz z dokonaniem przeglądu literatury (Bezpieczeństwo publiczne. Stany nadzwyczajne w Rzeczypospolitej Polskiej oraz Polskiej Rzeczpospolitej Ludowej 1918-2009, Toruń 2010, s. 205-208). Ta praca znana jest autorowi, dlaczego tym razem nie odwołał się do poczynionych tam ustaleń — nie wiadomo. 
Rozdziały 3-5 są przez autora zachwalane jako ,innowacyjne zaproszenie do badania prezydentury w praktyce politycznej i ustrojowej za pomocą politologicznej analizy decyzyjnej” (s. 15); w szczególności chodziłoby tu o zwrócenie uwagi na cybernetyczny typ analizy procesu podejmowania decyzji (rozdz. 3.3). Jednak już Arystoteles sugerował, że panem uczty nie jest kucharz lecz biesiadnicy, przestrzegając w ten sposób przed samozadowoleniem zainteresowanego, acz od razu można stwierdzić, że niektóre ustalenia poczynione $\mathrm{w}$ recenzowanej pracy są interesujące. Rozdział 3, zawierający analizę problemów teoretyczno-metodologicznych, jest uzasadniony również co do swej wielkości w rozprawie doktorskiej, chociaż na użytek trochę szerszego odbiorcy niż naukowe środowisko politologiczne mógłby ulec skróceniu. Nic nie straciłby na tym czytelnik recenzowanej książki.

Tematem rozdziału 4 jest realizacja zaproponowanego programu badawczego w odniesieniu do prezydentury gen. Wojciecha Jaruzelskiego. Otwiera tę część książki niejasne stwierdzenie, że Polskę lat 1944/1945-1989 cechowała „,fragmentaryczna suwerenność" (s. 150) - chodzi chyba o ograniczoną niepodległość państwa polskiego w tym okresie, bo państwo w sensie prawnomiędzynarodowym pozostawało w pełni suwerenne. Cokolwiek by nie rzec krytycznego o Trybunale Konstytucyjnym, Trybunale Stanu, Rzeczniku Praw Obywatelskich i Naczelnym Sądzie Administracyjnym, do utworzenia których doszło w schyłkowych latach istnienia PRL (s. 169), to stanowily one dobry fundament do zbudowania rządów prawa w Polsce po 1989 r., a ustawy o Trybunale Stanu czy RPO po koniecznych nowelizacjach obowiązują do dziś. Pisanie o Polsce po październiku 1956 r. jako państwie totalitarnym (s. 172) jest doprawdy przesadą, a przedstawiciel nauk politycznych powinien umieć rozróżniać między totalitaryzmem a posttotalitarnym autorytaryzmem. Akceptacja dla procesu finlandyzacji PRL mogła nastąpić ze strony ZSRS (s. 174) jedynie w momencie ustabilizowania sytuacji wewnętrznej w Polsce, do czego pod koniec 1981 r. było niepomiernie daleko. W tym momencie proklamacja stanu wojennego stawała się jedną z możliwych opcji ustrojowopolitycznych, a problem nie sprowadzał się do sięgnięcia po to urządzenie prawnokonstytucyjne tylko do tego, jaki użytek uczynił animator nocy grudniowej z uzyskanego zwycięstwa. Skoro Związek Sowiecki zgodził się na przywrócenie w wyniku nowelizacji kodeksu cywilnego z 26 marca 1982 r. norm obszarowych dla indywidualnych gospodarstw rolnych z dekretu PKWN z 6 września 1944 r. o reformie rolnej (Dz.U. nr 4, poz. 17), czyli 50 ha na ziemiach należących do Polski przed 1 września 1939 r. i 100 ha na ziemiach poniemieckich, to dlaczego nie miałby zaakceptować rozpoczęcia prywatyzacji mienia przedsiębiorstw państwowych, tym bardziej że istniało instrumentarium prawne to umożliwiające, albo przyjąć do wiadomości dalsze ułatwienia dla prowadzenia działalności gospodarczej w miastach? To powinny być sprawy ważne dla członka stowarzyszenia KoLiber, jakim jest autor, a nie jedynie rytualne wyrazy oburzenia z powodu decyzji zapadłych 12-13 grudnia 1981 r. W ten sposób nie tylko zwiększałby się zakres własności prywatnej w gospodarce, ale z czasem musiałoby to mieć wpływ na sposób rządzenia państwem. Czy to nie miałoby znaczenia dla konserwatywnego liberała?

Mimo tych krytycznych uwag jestem w stanie dostrzec wiele ciekawych konstatacji sformułowanych przez P. Momro w rozdziale 4. I tak na przełomie lat 1989/1990 „sto- 
sunek prezydenta [W. Jaruzelskiego - uwaga L.M.] do rządu [Tadeusza Mazowieckiego — uwaga L.M.] zmienia się z pozycji kohabitanta do roli życzliwego i powściągliwego sojusznika” (s. 162). Trudno nie zgodzić się z określeniem tej „prezydentury jako biernej i zarazem koncyliacyjnej, co miało się przejawiać głównie nikłym wykorzystaniem kompetencji ustrojowych oraz zgodą na skrócenie własnej kadencji, wyznaczonej pierwotnie na sześć lat" (s. 178). Podpisanie pakietu ustaw, składającego się na tzw. plan Balcerowicza, spowodowało, że „od tej pory, czyli od grudnia 1989 r., Jaruzelski jest sygnatariuszem i jednocześnie patronem politycznym całego procesu transformacyjnego", występując w efekcie w roli „współzałożyciela demoliberalnej III Rzeczypospolitej” (s. 201). I wreszcie ciekawa jest jedna z końcowych uwag: „Linię polityczną Jaruzelskiego można określić jako kombinację komunistycznej polityki historycznej z solidarnościowymi dążeniami do głębokiej rewizji dziejów XX wieku" (s. 223). Stanowisko to niejako antycypowało współcześnie realizowaną politykę historyczną Rosji, gdzie panteon bohaterów narodowych uzupełniony został o dowódców białych armii z okresu wojny domowej, ale bez rugowania ich bolszewickich zwycięzców.

$Z$ kolei rozdział 5 stanowi realizację programu badawczego w odniesieniu do prezydentury L. Wałęsy. Ten bardzo obszerny rozdział jest nareszcie napisany poprawnie. Nie można tu uczynić żadnych negatywnych uwag natury prawnokonstytucyjnej, zwraca uwagę ilość literatury i jej prawidłowe wykorzystanie. Chyba trafnie autor zauważył za największy sukces prezydentury L. Wałęsy uzyskanie przezeń od prezydenta Rosji Borysa Jelcyna w trakcie wizyty w Warszawie w sierpniu 1993 r. zgody na przystąpienie Polski do NATO. „W tamtych okolicznościach geopolitycznych i wszystkich słabościach państwa polskiego Wałęsa osiągnął więcej niż ktokolwiek mógł przewidzieć” (s. 343). Należy zgodzić się z opinią, że „tym, co prawdopodobnie odcisnęło największe piętno na psychice prezydenta, było ujawnienie na wielką skalę sprawy TW «Bolka», w wyniku przyjęcia przez Sejm uchwały lustracyjnej” (s. 259). Nie sądzę jednak, aby tłumaczenie przegranej przewodniczącego NSZZ „Solidarność” w starciu z A. Kwaśniewskim o urząd prezydenta RP agenturalną przeszłością tego pierwszego było trafne, jest to niczym nieuzasadniona przesada. Tak jak w wyborach parlamentarnych z $1993 \mathrm{r}$. wyborcy wystawili pod koniec $1995 \mathrm{r}$. rachunek za przebieg transformacji ustrojowej kolejnemu przedstawicielowi sił solidarnościowych. Prawdą jest natomiast, że gdyby zachowanie L. Wałęsy 4 czerwca 1992 r. było inne, to dziś pozycja historycznego przywódcy NSZZ „Solidarność” też byłaby bez porównania lepsza i nie byłoby tych wszystkich żenujących konfabulacji, których jesteśmy świadkami od ponad ćwierć wieku. Za trafne należy uznać stwierdzenie końcowe P. Momro, że celem L. Wałęsy było „skumulowanie jak największej władzy w swoim ręku oraz utrzymanie jak najwyższego poziomu popularności i poparcia dla jego osoby". W rezultacie chodziło o uzyskanie akceptacji dla drugiego prezydenta III RP ,jako ponadpartyjnego kierownika spraw państwowych i zarazem ,arbitra”, który pilnuje — a jednocześnie interpretuje — „czy program premiera i parlamentu jest zgodny z odczuciem społecznym i potem dokładnie realizowany" (s. 363). Przytoczony cytat to fragment odpowiedzi na pytanie o cele swojej prezydentury, jakiej L. Wałęsa udzielił w czasie kampanii wyborczej w 1990 r. Paradygmatyczny charakter miałyby tu stosunki ustrojowopolityczne, 
jakie ukształtowały się w 1991 r. w trakcie istnienia rządu Jana Krzysztofa Bieleckiego, czyli w praktyce dominacja głowy państwa nad Radą Ministrów i samym premierem. Próba przeniesienia tego na relacje z rządem Waldemara Pawlaka z początkowego okresu funkcjonowania koalicji SLD-PSL (1993-1995) zakończyła się jednak niepowodzeniem, co rozpoczęło ciąg chaotycznych konfliktów między ośrodkiem prezydenckim a większością parlamentarną. Konflikt ustrojowopolityczny był wzmagany przez fakt, że oba te ośrodki posiadały taki sam mandat, uzyskany bezpośrednio od narodu w wyborach powszechnych. Zresztą do dziś nie jesteśmy w stanie uporać się z tą konfliktogenną sytuacją. Zapewne nie da się tego skutecznie rozwiązać bez rezygnacji z powszechnych wyborów na urząd Prezydenta RP, bo nie sądzę, aby była możliwa w Polsce recepcja amerykańskiego modelu ustrojowego.

Krótkie podsumowanie nie wnosi już nic nowego do poczynionych uprzednio ustaleń, a jedynie stanowi powtórzenie w dobitny sposób znanych konkluzji z poprzednich części pracy. Teza, że „kluczowym dla utrzymania podstaw suwerennej pozycji politycznej jest kontrolowanie resortów obrony narodowej, spraw wewnętrznych i dyplomacji" (s. 380) nie jest specjalnie odkrywcza. W tym kontekście obaj pierwsi prezydenci III RP byliby jedynie uczniami marszałka Józefa Piłsudskiego z okresu po zamachu stanu z 12-15 maja 1926 r., przy czym przywódcę majowego rokoszu — takim terminem jako pierwszy posłużył się Stanisław Estreicher w artykule opublikowanym na łamach konserwatywnego „Czasu” już w trakcie walk w Warszawie - resort spraw wewnętrznych obchodził znacznie mniej niż dwa pozostałe. Tym, co szczególnie łączyłoby L. Wałęsę z J. Piłsudskim, był brak odpowiedzi na pytanie, w jaki sposób wykorzystać posiadaną władzę. Inna byłaby tu sytuacja W. Jaruzelskiego, który po kilku miesiącach urzędowania praktycznie zrezygnował z korzystania z konstytucyjnych kompetencji, ale dzięki temu nie powiększał się chaos panujący wówczas w Polsce. Nieco zaskakująco brzmi końcowy wniosek, że „potencjał Wałęsy jako karty przetargowej nie został w pełni wykorzystany w polskiej polityce zagranicznej”, warto jednak pamiętać, że jest to powtórzenie wcześniej formułowanego i odpowiednio uzasadnionego stanowiska autora.

Bez wątpienia należy uznać za udowodnioną tezę, że kompetencje prezydenckie $\mathrm{z}$ lat 1989-1995 stanowią istotny instrument $\mathrm{w}$ realizowaniu linii politycznej osoby piastującej urząd Prezydenta PRL / Prezydenta RP. Na podkreślenie zasługuje nie tyle oryginalność powyższej tezy, co fakt poddania jej wielostronnym analizom o charakterze zarówno prawnokonstytucyjnym, jak i politologicznym.

Recenzowana książka zapewne nie stanie się klasyczną pozycją z zakresu nauk politycznych, nawet odnośnie badanego okresu. Zadecyduje o tym zbyt dużo błędów i schematycznych uproszczeń w niej zawartych. Jej wartość podnosi staranne wydanie, wyrazista okładka i dobra korekta, co autor zawdzięcza Wydawnictwu von borowiecky, ale to zbyt mało, żeby praca Pawła Momro mogła uzyskać w pełni pozytywną ocenę.

Lech Mażewski*

* Dr hab. Lech Mażewski, prof. Wyższej Szkoły Administracji i Biznesu

im. E. Kwiatkowskiego w Gdyni, doradcy@wp.pl, https://orcid.org/0000-0002-0662-2260 